\title{
Process Approach in the Teaching of Writing for Undergraduate EFL Students
}

\section{K. Yogi Setyawan ${ }^{1}$, N. M. Ratminingsih ${ }^{2}$, N. K. Arie Suwastini ${ }^{3}$}

Universitas Pendidikan Ganesha, Indonesia

Email Correspondence: setyawan.ogi@gmail.com

\section{Background:}

Abstract

This research aimed to investigate the implementation of a process approach for EFL undergraduate students in a private university in Bali.

\section{Methodology:}

The present study involved one lecturer and thirty students enrolled in Paragraph Writing Class. Observations were conducted in twenty-eight meetings of the total meetings to reveal - that strategies of process approach were implemented in each of the stages of writing, namely, prewriting, drafting, editing, revising and, publishing.

Findings:

The lecturer implemented all nine strategies where seven strategies were optimally conducted and all ten strategies were implemented by the students, where nine strategies were optimally conducted during the editing stage. In the publishing operation, the instructor implemented three of three strategies, and students implemented three of three strategies.

\section{Conclusion:}

Strategies of process approach were implemented by the lecturer and the students during the Paragraph Writing Course. It is implied that in an implementation of a process approach in a writing class, the lecturer and the students need to work together in most of the stages to create a good writing process.

Keywords: paragraph writing course; process approach; writing stages.

\begin{tabular}{|c|c|c|}
\hline DOI & : & http//dx.doi.org/10.24903/sj.v5i2.520 \\
\hline Received & : & August 2020 \\
\hline Accepted & : & September 2020 \\
\hline Published & : & October 2020 \\
\hline Copyright Notice & : & $\begin{array}{l}\text { Authors retain copyright and grant the journal right of first publication with the } \\
\text { work simultaneously licensed under a Creative Commons Attribution } 4.0 \\
\text { International License that allows others to share the work with an acknowledgment of } \\
\text { the work's authorship and initial publication in this journal. } \\
\text { cc) (1) (O) }\end{array}$ \\
\hline
\end{tabular}

\section{INTRODUCTION}

The process approach is one of the writing approaches that are used in Indonesian schools and universities. As defines by Nunan (1991, 2003), the process approach is an approach in writing pedagogy that is focused on several classroom activities and it believes to lead the students to develop the skill of language use. The process approach is believed to help students in writing more systematically and reduce writing anxiety (Arici \& Kaldirim, 2015). As mentioned by Atay and Kurt (2006), learning writing as a predominantly product-oriented in another language gives as much anxiety as learning the other skills. Ratminingsih (2015) also summarized four common problems faced by Indonesian students in writing, namely difficulties in conveying their thought in foreign language writing, lack of vocabulary, 
coherence in organizing ideas, and fear of committing grammatical errors. As mentioned by Gustilo and Magno (2015) that writing in a second and foreign language is difficult; it is proven by the quality of the second language writing by the students is lowest than their first language writing. Moreover, Suwastini and Yukti (2017) mention that writing is very complicated because it involves the need to write grammatically so that these expressions can be understood for Indonesian students who learn English as a foreign language (EFL).

Since writing is not a spontaneous activity where it reflected students' knowledge and the way they think, the process approach is conducted to train students to generate their idea, determine the purpose and the audience, and communicate their thought by writing and improving several drafts (Merilia et al., 2019; Ratminingsih et al., 2018; Sharifi \& Hassaskhah, 2011; Yusof, 2009). This approach aims to train the students to generate and plan their writing ideas, consider the audience, draft, and redrafting, and emphasize writing as a process (Arici \& Kaldirim, 2015; Brannan, 2003; Kim \& Kim, 2005; Sheir et al., 2015). Five phases follow the implementation of the process approach in the classroom: prewriting, drafting, revising, editing, and publishing or sharing (Johnson, 2008; McIntyre et al., 2011; Sheir et al., 2015; Vanderpyl, 2012).

Due to the effectiveness of the process approach, lecturers in Universitas Mahasaraswati Denpasar claimed that they have been applying the process approach in their writing classes. Bearing in mind that process approach needs strong commitment on the how-to instructional process is conducted to emphasize that the process becomes the focus, instead of the product, the present study observed the implementation of the process approach in a Paragraph Writing Class to elaborate whether or not the strategies or process approach had been implemented properly. The present study observed both the strategies employed by the teachers and the activities conducted by the students to determine whether the lecturer had applied the strategies and whether the students had been involved in the process actively.

\section{METHODOLOGY}

To collect the data, the Observation technique is used in this study, and the researcher was the main instrument with the observation protocol checklist as a supporting instrument. This study was focused on observing the implementation of the process approach in the English Language Education Study Program and thirty second-semester students were enrolled in the Paragraph Writing Course. The observation was conducted in twenty-eight meetings. After the data was collected, the data was organized by tabulating the data into the form of students' and lecturer's data in every phase of the process approach. The descriptions of the strategies used 
by the lecturer and students in writing activity were compared to the parameter that had been summarized from the previous research and theory.

\section{FINDINGS}

In the implementation of the process approach in learning writing, there were five phases carried out by both lecturer and the students. The lecturer's implementation of the process approach is shown in Table 1, while the students' activity during the implementation of the process approach is shown in Table 2.

Table 1. The Implementation of Process Approach by the Lecturer

\begin{tabular}{|c|c|c|c|c|}
\hline Phase & Strategies & $\mathbf{S}$ & $\mathbf{A}$ & ND \\
\hline \multirow{7}{*}{ Prewriting } & 1. Lecturer focuses on the process of the writing not only the final product of the & $\sqrt{ }$ & & \\
\hline & $\begin{array}{l}\text { Writing } \\
\text { 2. Lecturer helps the students in the composing process of their writing }\end{array}$ & $\sqrt{ }$ & & \\
\hline & 3. Lecturer helps the students in collecting and organizing the data & & $\sqrt{ }$ & \\
\hline & 4. The lecturer provides sufficient time in the prewriting process & $\sqrt{ }$ & & \\
\hline & $\begin{array}{l}\text { 5. Lecturer give the students freedom in choosing the topic that they are going to } \\
\text { write }\end{array}$ & & $\sqrt{ }$ & \\
\hline & 6. Lecturer gives the students feedback for their outline & $\sqrt{ }$ & & \\
\hline & $\begin{array}{l}\text { 7. Lecturer invites the students to make discussion and getting feedback from the } \\
\text { other students }\end{array}$ & $\sqrt{ }$ & & \\
\hline \multirow{7}{*}{ Drafting } & 8. Lecturer revise and assess the students' outline & & $\sqrt{ }$ & \\
\hline & 1. Lecturer asks the students to write their data into a first draft. & $\sqrt{ }$ & & \\
\hline & 2. Lecturer helps the students to understand their own draft. & & $\sqrt{ }$ & \\
\hline & 3. Lecturer gives the students time to write & $\sqrt{ }$ & & \\
\hline & 4. Lecturer helps the students to build repertories strategies for drafting & & $\sqrt{ }$ & \\
\hline & 5. Lecturer assists students who are having difficulties with how to start writing. & $\sqrt{ }$ & & \\
\hline & 6. Lecturer helps students understand their own composing process & & & $\sqrt{ }$ \\
\hline \multirow{8}{*}{ Revising } & 1. Lecturer helps the students to build repertories strategies for revising & $\sqrt{ }$ & & \\
\hline & 2. Lecturers place the central importance of the revision & $\sqrt{ }$ & & \\
\hline & $\begin{array}{l}\text { 3. Lecturer gives the students chance to encourage feedback from the lecturer and } \\
\text { their friend }\end{array}$ & $\sqrt{ }$ & & \\
\hline & $\begin{array}{l}\text { 4. Lecturer provides individual conferences between teacher and students during } \\
\text { the process of composition }\end{array}$ & & $\sqrt{ }$ & \\
\hline & 5. Lecturer asks the students to do self-revision and pair or group revision & $\sqrt{ }$ & & \\
\hline & 6. Lecturer revises the students' draft & $\sqrt{ }$ & & \\
\hline & 7. Lecturer gives the students feedback on their writing & $\sqrt{ }$ & & \\
\hline & $\begin{array}{l}\text { 8. Lecturer checks the content, context, assessing impact, connection and } \\
\text { organization of the student's text }\end{array}$ & $\sqrt{ }$ & & \\
\hline \multirow{11}{*}{ Editing } & 9. Lecturer checks the originality of students' writing & $\sqrt{ }$ & & \\
\hline & $\begin{array}{l}\text { 1. Lecturer asks the students to edit their text (read aloud, check the sentences and } \\
\text { the organization) }\end{array}$ & $\sqrt{ }$ & & \\
\hline & 2. Lecturer gives the students time to conduct the editing process & $\sqrt{ }$ & & \\
\hline & $\begin{array}{l}\text { 3. Lecturer conducts individual conferences between lecturer and students during } \\
\text { the process of composition }\end{array}$ & & $v$ & \\
\hline & 4. Lecturer gives the students feedback throughout the writing process, not only & & & \\
\hline & $\begin{array}{l}\text { in the final product, as the students attempt to bring their expression closer and } \\
\text { closer to the intention }\end{array}$ & $\sqrt{ }$ & & \\
\hline & $\begin{array}{l}\text { 5. Lecturer gives the students chance to encourage feedback from the instructor } \\
\text { and the peers }\end{array}$ & $\sqrt{ }$ & & \\
\hline & 6. Lecturer helps the students in the editing process & $\sqrt{ }$ & & \\
\hline & 7. Lecturer gives students feedback on their writing & $\sqrt{ }$ & & \\
\hline & 8. Lecturer asks the students to do a final revising with their pair or group & $\sqrt{ }$ & & \\
\hline & 9. Lecturer helps students to build repertoires of strategies for editing & & $v$ & \\
\hline
\end{tabular}




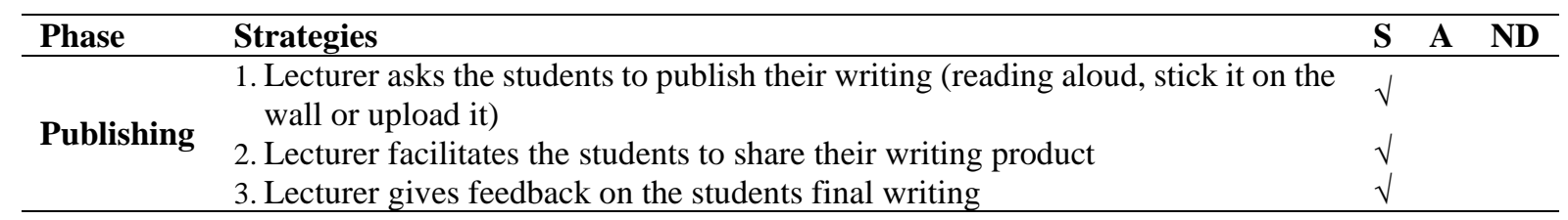

Explanation: S (Strong); A (Apparent); ND (Not Displayed)

Table 1. The Implementation of Process Approach by the Students

\begin{tabular}{|c|c|c|c|c|}
\hline Phase & Strategies & $\mathbf{S}$ & $\mathbf{A}$ & ND \\
\hline \multirow{10}{*}{ Prewriting } & 1. Students choose their own topic & & $\sqrt{ }$ & \\
\hline & 2. Students determine the goal of their writing & & & $\sqrt{ }$ \\
\hline & 3. Students determine the audience of their writing & & & $\sqrt{ }$ \\
\hline & 4. Students revise and assess their idea & & $\sqrt{ }$ & \\
\hline & 5. Students plan the strategies of prewriting & & $\sqrt{ }$ & \\
\hline & 6. Students do brainstorming & $\sqrt{ }$ & & \\
\hline & $\begin{array}{l}\text { 7. Students collect their data (reading, exploring the internet, conducting the } \\
\text { discussion, listing, noting and outlining) }\end{array}$ & $\sqrt{ }$ & & \\
\hline & $\begin{array}{l}\text { 8. Students organize their idea (word mapping, clustering, mind mapping and } \\
\text { branching) }\end{array}$ & $\sqrt{ }$ & & \\
\hline & 9. Students conduct free writing (free writing and quick writing) & $\sqrt{ }$ & & \\
\hline & 10. Students prepare the scratch outline of their writing & $\sqrt{ }$ & & \\
\hline \multirow{10}{*}{ Drafting } & 1. Students prepare the enjoyable workspace & & & $\sqrt{ }$ \\
\hline & 2. Students specify the topic & & & $\sqrt{ }$ \\
\hline & 3. Students develop meaning from the idea & & $\sqrt{ }$ & \\
\hline & 4. Students remove or add information & & $\sqrt{ }$ & \\
\hline & 5. Students write a rough draft & $\sqrt{ }$ & & \\
\hline & 6. Students use the outline as a guide to writing the draft & $\sqrt{ }$ & & \\
\hline & 7. Students determine the form of organization that is going to be written & & $\sqrt{ }$ & \\
\hline & 8. Students search a good strategy to attract the reader & & & $\sqrt{ }$ \\
\hline & 9. Students move ahead and focus on the content rather than mechanics & $\sqrt{ }$ & & \\
\hline & 10. Students getting or giving feedback & $\sqrt{ }$ & & \\
\hline \multirow{10}{*}{ Revising } & 1. Students read aloud the text & & & $\sqrt{ }$ \\
\hline & 2. Students fix the big issues of content, context and organization & $\sqrt{ }$ & & \\
\hline & $\begin{array}{l}\text { 3. Students add, delete, modify and re-arranging details that is appropriate with } \\
\text { the topic }\end{array}$ & $\sqrt{ }$ & & \\
\hline & 4. Students do proofreading & & $\sqrt{ }$ & \\
\hline & 5. Students pretend to be the reader of their writing & & & $\sqrt{ }$ \\
\hline & 6. Students do group or pair revising by making discussion & $\sqrt{ }$ & & \\
\hline & 7. Students Add or check all of the sources as a quotation & $\sqrt{ }$ & & \\
\hline & 8. Students conduct self-revising & $\sqrt{ }$ & & \\
\hline & 9. Students conduct peer/group revising & $\sqrt{ }$ & & \\
\hline & 10. Students conducting expert revising & $\sqrt{ }$ & & \\
\hline \multirow{10}{*}{ Editing } & $\begin{array}{l}\text { 1. Students check the language use (grammar, vocabulary, linkers), punctuation } \\
\text { (and layout), spelling and sentence structure }\end{array}$ & $\sqrt{ }$ & & \\
\hline & 2. Students check the unnecessary word or information repetition & $\sqrt{ }$ & & \\
\hline & 3. Students check the gap of their writing & & $\sqrt{ }$ & \\
\hline & 4. Students conduct self-editing & $\sqrt{ }$ & & \\
\hline & 5. Students conduct pair/group editing & $\sqrt{ }$ & & \\
\hline & 6. Students use the computer to edit their paragraph & $\sqrt{ }$ & & \\
\hline & 7. Students take advantages from other input & $\sqrt{ }$ & & \\
\hline & 8. Students review slowly and repeatedly & $\sqrt{ }$ & & \\
\hline & 9. Students track the error types & $\sqrt{ }$ & & \\
\hline & 10. Students write the final copy of their writing & $\sqrt{ }$ & & \\
\hline \multirow{4}{*}{ Publishing } & 1. Students produce their final document & $\sqrt{ }$ & & \\
\hline & 2. Students publish their writing into the appropriate form (reading aloud, display & & & \\
\hline & $\begin{array}{l}\text { it on the classroom or school wall, send it to learning sites that others can read } \\
\text { it) }\end{array}$ & $\sqrt{ }$ & & \\
\hline & 3. Students share their writing to the teacher & $\sqrt{ }$ & & \\
\hline
\end{tabular}

Explanation: S (Strong); A (Apparent); ND (Not Displayed) 
In the prewriting activities, students followed eight out of ten strategies where six strategies were implemented optimally, and two strategies were apparent but weakly implemented. In drafting activities, seven out of the ten strategies were carried out by the students, where four strategies were fully implemented, and three strategies were implemented weakly. In the revising activities, from ten strategies, eight strategies were carried out, where seven strategies were conducted strongly, and one strategy was weakly performed. Then in the editing activity, nine out of ten strategies were done by the students where nine strategies were conducted optimally, and one strategy was apparent but weakly implemented. While in the publishing activity, all of the three strategies were fully conducted by the students.

\section{DISCUSSION}

In implementing the process approach in the paragraph writing course, the lecturer and the students implemented phases that were consisted of invention phases (prewriting), writing phase, and improving phase (revising and editing) that is purposed by Nunan (2003). Those stages were developed into five phases such as prewriting, drafting, revising, editing, and publishing as that phase were known as the typical phase that is implemented in the process approach in writing pedagogy (Arici \& Kaldirim, 2015; Habtamu, 2018; Johnson, 2008; McIntyre et al., 2011; Samsudin, 2016; Sheir et al., 2015; Sun \& Feng, 2009; Vanderpyl, 2012).

From the lecturer's point of view, the implementation of the process approach is carried out by following five phases of writing. In the prewriting activity, it can be seen that the lecturer implemented all of the eight strategies within the parameters where five strategies were implemented optimally, and three strategies were apparent but weakly implemented. In the drafting activity, the lecturer implemented all of the six strategies within the parameter where three strategies were fully implemented, and the other three strategies were weakly implemented. In revising the activity, it appears that the lecturer applied all of the nine strategies where eight strategies were implemented optimally, and one strategy was not implemented optimally. Likewise, in the editing phase, the lecturer applied all of the nine strategies where seven strategies were conducted optimally, and two strategies were apparent but weakly implemented. Furthermore, in the publishing activity, all of the three strategies in the parameter were fully implemented by the lecturer.

In the following parts, the implementation of the process approach in each of the stages will be elaborated more thoroughly. 


\subsection{Prewriting}

In this phase the students find the idea to write by choosing the topic, collecting and exploring the information about the idea with guidance from the lecturer, as mentioned by Nunan (2003); Oshima and Hogue (2007); Sun and Feng (2009).

It can be observed from Table 1 that the lecturer carried out all of the eight strategies, where five strategies were implemented optimally, and three strategies were apparent but weakly implemented. The five strategies that were implemented optimally by the lecturer namely the lecturer focused on the process of writing not only the final writing product, but the lecturer also helped the students in the comprising process of their writing, lecturer provided sufficient time in the prewriting process, the lecturer gave the students feedback for their outline, and lecturer invites the students to make discussion and to get feedback from the others. Brown (2001) mentions that the implementation of the process approach should not be focused on the final writing product but the process of writing. Thus, it was found that the lecturer implemented the prewriting phase optimally as the lecturer helped and guided the students in exploring information during composing their writing (Nunan, 2003; Oshima \& Hogue, 2007; Sun \& Feng, 2009). Further, Brown (2001) also mentions that the lecturer should give students sufficient time, assist them in the composing process, and give them feedback both individually and in group discussion. This is also supported by Adula (2018); Brannan (2010); Harmer (2007); McIntyre, Hulan, and Layne (2011); and Nabhan (2017) that mention the importance of giving the students time to write and in assisting the students during the activity of prewriting. Thus, in the classroom implementation, it had been done by the lecturer where the students were assisted in the composing process, giving them feedback and giving time for them to write which shows that the five strategies were implemented optimally by the lecturer.

According Nunan (2003); Oshima and Hogue (2007); Sun and Feng (2009) prewriting phase requires students to find the idea to write by choosing the topic, collecting and exploring the information about the idea with guidance from the lecturer. Further, from those strategies that were fully implemented by the lecturer, three strategies were apparent but weakly implemented. Those strategies are lecturer helped students in collecting and organizing data, the lecturer gave the students freedom in choosing the topic that they are going to write, and lecturer revised and assessed the students' outline. In the classroom implementation, the topic that was used by the students was provided by the lecturer; which the students were allowed to develop it. Thus, the implementation is not fully in line with the theory that is formulated from Brannan (2010); McIntyre et al. (2011); Oshima and Hogue (2007); Samsudin (2016), stated that the freedom in choosing the topic of writing should be fully given to the students. Further 
implementation was the lecturer gave the students freedom to collect and organize their data; the lecturer only answered questions asked by several students, and not all of the students were directly helped in this process. Whereas Nunan (2003); Oshima and Hogue (2007); Sun and Feng (2009) mentions that the prewriting phase requires guidance from the lecturer, which shows that the strategy was weakly implemented. Moreover, Brown (2001) mentions that students should be helped in collecting and organizing the data of prewriting. Finally, at the end of the prewriting phase, students finished their outline and should be given revision. According to Eliwarti and Maarof (2006) and Sun and Feng (2009), the revision is given to the students' outlines by the lecturer in the prewriting activity and the lecturer in conducting the revising activity did not revise all of the outlines from the students. However, in the classroom implementation, when the students finished their outline, only a few students get a chance to be revised and assessed by the lecturer.

Students conducted eight out of ten strategies of prewriting. Five strategies were implemented optimally, and three strategies were apparent but weakly implemented. The strategies that are optimally implemented were brainstorming, collecting the data, organizing the data, freewriting, and preparing the scratch outline of the writing. In the classroom implementation, students in conducting prewriting activity started by brainstorming and collecting the data. Nunan (2003) supported by Adula (2018); Brannan (2010); McIntyre, Hulan, and Layne (2011); Samsudin (2016); Sheir, Zahran, and Koura (2015); Sun and Feng (2009); Harmer (2007); and Nabhan (2017), also mention that students must be given a sufficient time to conduct brainstorming activity and collecting the data by reading, exploring the internet, conducting discussion making list and outlining. Further, the students' activity was proceeded by organizing the data and conducting free writing. This is in line with Adula (2018); Brannan (2010); Hasan and Akhand (2010); McIntyre et al. (2011); Nabhan (2017); Nunan (2003); Oshima and Hogue (2007); Samsudin (2016); Sheir et al. (2015); Sun and Feng (2009); Vanderpyl (2012) that the prewriting activity should be conducted by the students which in this study was found to be optimally implemented especially in the brainstorming, collecting the data, organizing the data, freewriting, and preparing the scratch outline of the writing.

There are also three out of ten strategies that were implemented by the students that were apparent but weakly implemented. Those strategies are choosing the topic, revising and assessing the idea, and planning the strategies of prewriting. Adula (2018); McIntyre et al. (2011); Nabhan (2017) mention that choosing the topic should fully be given to the students, however, in the classroom implementation the students did not fully allow choosing the topic but they must develop the main topic that was given by the lecturer. This might be done by the 
lecturer to simplify the assessment; after all, even though the students only developed the main topic from the lecturer, it did not limit students in developing their writing. After the students had finished their outline, only several students were asked to read it aloud so it can be revised and assessed by the lecturer; whereas mentioned by Sun and Feng (2009), the student's outline should be revised and assessed by the lecturer. In planning the prewriting strategy the students were guided by the lecturer in general term, and the students did not conduct it independently, as it is suggested by Adula (2018); Brown (2001); Eliwarti and Maarof (2006). Moreover, two strategies were not implemented by the students; determining the goal and the audience of the writing as it was suggested by Arici and Kaldirim (2015); Brannan (2010); and McIntyre et al. (2011).

\subsection{Drafting}

The drafting stage was conducted by the lecturer to ask the students to develop their outline into a draft without worrying about the mechanics (grammar, spelling, and punctuation) and language accuracy. This activity of the lecturer and the students were referring to theories from Alodwan and Ibnian (2014); Arici and Kaldirim (2015); Gonzalez (2010); Hasan and Akhand (2010); McIntyre et al. (2011); Nabhan (2017); Sheir et al. (2015) that will be discussed in the following discussion.

As shown from the result of the observation, the lecturer implemented five out of six strategies in the drafting phase. Three strategies were implemented optimally, and two strategies were apparent but weakly implemented. Three strategies that were implemented optimally are the lecturer asked the students to write the final draft, gave the students sufficient time to write, and assisted the students who were having difficulties in the writing process. During the drafting process in the classroom, the lecturer invited the students to write their draft with the guidance of their outline, which is in line with a statement referring to a theory by Brown (2001). Moreover, Brown (2001)mentions that sufficient time should be given to the students in this process, therefore, during the classroom implementation the lecturer asked the students to write their time in their house so that the students had enough time to compile their draft. Lecturer also assisted the students who were having difficulties in this process by allowing them to ask questions related to this process which is also in line with the statement from Brown (2001); Nunan (2003); Sun and Feng (2009), that lecturer should assist students who were having difficulties during the process of drafting.

In the implementation of drafting, the lecturer conducted two strategies that were apparent but weakly implemented. Those strategies are the lecturer helped the students to understand 
their draft and build repertories strategy for drafting. As mentioned by Brown (2001), lecturer action in helping students to understand their draft and building repertories strategy will help students in the drafting process. However, in the classroom implementation, the lecturer only helped a few students in the drafting process where the lecturer only helped students who wrote their draft in the classroom meeting. Moreover, the lecturer did not help the students to understand their composing process; the students freely conducted the activity and wrote their draft independently, whereas referring to Brown (2001) mentions that students should be guided in understanding their composing process.

There are seven out of ten strategies implemented where four strategies were implemented strongly, and three strategies were weakly apparent by the students. Those activities are writing the rough draft, using the outline as a guide, moving ahead and focusing on the content rather than the mechanics, and getting or giving feedback were conducted optimally by the students. According to Nunan (2003), the students can use their outline as guidance in writing the draft without worrying about the systematical correctness. Thus, in the classroom implementation, the students made their outline and used it as a guide in writing their draft. Moreover, Arici and Kaldirim (2015); Brannan (2010); McIntyre et al. (2011); Oshima and Hogue (2007) also mentions the focus of drafting that is forming the idea into the first writing without worrying about the mechanical correctness such as grammar, punctuation and spelling. Moreover, according to Nunan (2003); Sun and Feng (2009) suggested that the student should form a group discussion to give and receive feedback. In the classroom observation, it was found that the students also formed a group discussion to give and get feedback in this writing process.

Further, three strategies were weakly implemented by the students, namely developing meaning from the idea, removing and adding information, and determining the form of organization that is going to be written. Arici and Kaldirim (2015); Nabhan (2017); Sheir, Zahran, and Koura (2015) mention that these three strategies better be conducted by the students to develop their writing. However, several students only formed their idea in the outline to a draft without developing the meaning from the idea or adding and removing information or develop their idea into the appropriate organization in the drafting process. Moreover, three strategies were not shown to be implemented by the students. Those strategies were preparing the enjoyable workspace, specifying the topic, and searching the good strategy to attract the reader. At the same time, Brannan (2010) states that the writer needs to prepare an enjoyable space to write, but because the students mostly conducted the writing in their house and it could not be seen whether the students had done it or not. Students also did not specify the topic of their outline, and they did not emphasize how to attract readers for their 
writing since they were also not determining the reader of their writing. Referring to Brannan (2010) and McIntyre et al. (2011), specifying the topic of their outline and emphasizing to attract readers for their writing should be conducted by the students in their writing.

\subsection{Revising}

In revising activity, the students focus on the correctness of their writing; they need a different approach to see their writing from different perspectives so they can see the mistakes or inappropriate part of their writing. Revising helps the students to identify their writing level as a writer to improve their writing skills (Suwanarak, 2018). The main goal of revising is to clarify, rewrite in the proper structure, reorganize the piece, add text and remove irrelevant materials (McIntyre et al., 2011).

In the revising activity, all nine strategies were conducted by the lecturer, where only one strategy was apparent but weakly implemented. The strategies that fully conducted were lecturer helped the students to build repertories strategy for revising; placed the central importance of the revision; gave students chance to encourage feedback from the lecturer and their friend; asked students to conducted self, pair, and group discussion; revised the students draft; gave the students feedback; checked the general correctness; and checked the originality of the students writing. Brown (2001) also mentions that students should be helped in determining what they should do in revising activity. Moreover, the lecturer during revising activity should guide the students to plan the strategies that they can use in this activity. Brown (2001) also mentions that the central importance of the writing should be put on the revising activity where the students are provided with the chance to encourage feedback from the others; which these strategies that suggested by Brown (2001) had been implemented by the lecturer in the writing activity. According to Adula (2018); Brown (2001); McIntyre et al. (2011); Nabhan (2017); Oshima and Hogue (2007) lecturer should invite students to conduct self, pair, group, and expert discussion. Thus, in the classroom implementation, the lecturer also invited students to conduct self, pair, group, and expert (with the lecturer) discussion as it mentioned in theory by Adula (2018); Brown (2001); McIntyre et al. (2011); Nabhan (2017); Oshima and Hogue (2007). Further, according to Fulwiler (2002); McIntyre et al. (2011); Nunan (2003); and Sheir et al. (2015) the strategies that should be implemented by the lecturer are giving students feedback, checking the content, context, assessing impact, connection, organization and the originality of the students writing. Thus, it was found in the classroom implementation that the lecturer had implemented the strategies by giving the students feedback, checking the content, context, assessing impact, connection, organization, and the originality of the students 
writing. However, there is one strategy that was apparent but weakly implemented by the lecturer, namely not giving students the chance to conduct the individual conference. Whereas referring to Brown (2001) mentions that it is better to conduct an individual conference between lecturer and students in the revising process. However, during the classroom implementation, not all students were given a chance to conduct an individual conference between the lecturer and the students.

Besides, there are eight out of ten strategies that were implemented by the students, seven strategies were conducted optimally, and one strategy was weakly implemented. Students fixed the big issues of their writing; added, deleted, modified, and re-arranged details that is appropriate with the topic; conducted discussion; checked all of the sources as the quotation; conducted self-revising; conducted peer and group revising; and conducted expert revising. Further, during the revising activity, the students focused on fixing the content, context, and organization of their writing by adding, deleting, modifying, re-arranging the details that is appropriate with the topic as those suggested by Arici and Kaldirim (2015); Brannan (2010); Brown (2001); Harmer (2003); McIntyre et al. (2011); Oshima and Hogue (2007); Samsudin (2016); Sheir et al. (2015); Sun and Feng (2009). Students also revised their writing by conducting the discussion in group and pair after they had done the self-revising which is supported by Adula (2018); Brannan (2010); McIntyre et al. (2011); Nabhan (2017); Oshima and Hogue (2007); and Sheir et al. (2015) mention about the importance of group self, group/pair and expert revising in classroom discussion. McIntyre et al. (2011) also state that the student should check the originality of their writing. Thus, from the observation, it was found that the students also checked the originality of their writing helped by the lecturer by checking the sources and the quotation used in their writing. However, proofreading activity, as suggested by Brannan (2010); Nunan (2003); Sun and Feng (2009), was not conducted optimally by all of the students. Moreover, the students were found not to read the text aloud and did not pretend to be the reader of their writing, as suggested by McIntyre et al. (2011).

\subsection{Editing}

In the editing phase, students focus on checking the writing mechanics, checking gathered data for accuracy utility, and completeness and clarify the ideas (Fulwiler, 2002; Hogue, 2008; McIntyre et al., 2011; Oshima \& Hogue, 2007; Samsudin, 2016; Sheir et al., 2015; Singh, 2006). Unlike the revising process, the editing step is focused on evaluating the mechanics of the writing, such as spelling, punctuation, grammar as much as possible (Brannan, 2003; Harmer, 1991; Nunan, 2003). 
As can be observed from Table 1, from nine strategies lecturer implemented nine strategies; eight strategies were strongly apparent, and two strategies were weakly apparent. From the observation it was found that the lecturer asked the students to edit their text; gave the students time to edit; gave the students feedback throughout the writing process not only the final writing product; gave the students chance to encourage feedback; helped the students; gave feedback of their writing, and asked the students to conduct final revising with the pairs or group. The activity of editing was conducted consecutively in two until three meetings to help the students in revising and editing practice. Thus, Adula (2018); Brannan (2010); Brown (2001); McIntyre et al. (2011); Nabhan (2017); Oshima and Hogue (2007); Sheir et al. (2015) also mention the importance of editing process and sufficient time that should be given to the students in this writing process. Lecturer also focused the activity of writing in the editing and revising activities where the students were given feedback from peers and instructor during the process of editing not only in the final writing product just in line with the statement from Brown (2001) which mentions that the lecturer should give students feedback during the process of editing as well as feedback for the final writing product. Through the observation, it was also found that the students were helped by the lecturer and asked the students to the conducted final revising product before producing the final draft that was going to be published. Referring to Brown (2001); Oshima and Hogue (2007) also states about the activity of final revising before the writing is published.

Furthermore, two other strategies were apparent but weakly implemented by the lecturer. Those strategies are the individual conference between the students and the lecturer during the process of composition and the help from the lecturer in building the repertoire strategies for editing. Brown (2001) and Nunan (2003) mentions that the lecturer should conduct an individual conference with the students, however in the implementation of the process approach; the lecturer only conducted an individual conference with few students since the number of the students in the classroom that was too big and the limitation of the time. Lecturer also helped students to build the repertoires strategy for editing in the general term when students were only asked to fix the grammatical issues of the writing, whereas Brown (2001) mentions that the students should be given an overview of what are they going to do.

In the editing activity, the students conducted all ten strategies in the parameter. As can be observed from the table, students conducted nine out of ten strategies optimally, and only one strategy was apparent but weakly implemented. It was observed that the students checked the language use; an unnecessary word or information repetition; they conduct self, pair, or group editing; use a computer to edit their text; take advantages of the other input; review slowly and 
repeatedly; track the error types, and write the final copy of their writing. As mentioned by Adula (2018); Harmer (2003), (2007); McIntyre et al. (2011); Nabhan (2017); Oshima and Hogue (2007); Sheir et al. (2015) editing process is focused on checking the language use (grammar, vocabulary, linkers), punctuation (and layout), spelling, sentence structure and the unnecessary word or information repetition, wherein the classroom implementation the students have done checking the language use, punctuation, spelling, sentence structure and the unnecessary word or information repetition during revising activity. Students have also conducted self, pair, or group editing and using a computer to edit their text to take advantage of the other input which is referring to a statement from Brannan (2010); Oshima and Hogue (2007). Moreover, Adula (2018); Brannan (2010); Harmer (2007); Sheir et al. (2015) state that students should edit slowly, repeatedly, and track the error type they might make, where the students had done it in the activity of editing. Further, Adula (2018); Brannan (2010); Harmer (2007); Sheir et al. (2015) suggested that before the writing got published, the students should prepare the final copy of their writing. Thus, from the observation in the classroom, the student had prepared the final copy of their writing. There was also one strategy that was apparent but weakly implemented, which was not all of the students were aware to check the gap among the sentence of their writing as suggested by Vanderpyl (2012).

\subsection{Publishing}

In this activity, the students publish their final writing facilitated by the lecturer to build their confidence and instill students' thoughts that the writing process they have done was not in vain. Buhrke (2002) in Sheir et al. (2015) mentions the importance of publishing to help students creating real communication between writers and readers in the process of writing in the classroom. In this activity, the students and the lecturer conducted all of the strategies optimally. From the observation, the lecturer asked the students to publish their writing by uploading it on the Schoology learning app, and it was facilitated by the lecturer with the room chat so that students could conduct a discussion. This is referring to Brown (2001) mentions that the feedback was also given to students final as the lecturer gave the students points and gave comments and suggestions to their writing. Furthermore, students published their writing by sending it to the Schoology learning app after producing the final document that had been edited and revised previously. This activity is in line with the statement from Adula (2018); Arici and Kaldirim (2015); Eliwarti and Maarof, (2006); Harmer (2007); McIntyre et al. (2011); Samsudin (2016); Sheir et al. (2015) that also suggested the students publish their writing in several ways to improve the confidence and pride in writing. 


\section{CONCLUSION}

The observation that had been conducted showed that the lecturer followed five phases of writing: prewriting, drafting, editing, revising, and publishing. In implementing the process approach in the classroom, the students used some strategies and controlled by the lecturer. The observation also showed some differences that were raised in the writing activity. Those differences related to the lecturer's strategies and the students' contribution to the learning activity and the emphasis of the phases of the process approach.

\section{REFERENCES}

Alodwan, T. A. A., \& Ibnian, S. S. K. (2014). The effect of using the process approach to writing on developing university students' essay writing skills in EFL. Review of Arts and Humanities, 3(2), 139-155. http://rahnet.com/journals/rah/Vol_3_No_2_June_2014/11.pdf

Arici, A. F., \& Kaldirim, A. (2015). The effect of the process-based writing approach on writing success and anxiety of pre-service teachers. The Anthropologist, 22(2), 318-327. https://doi.org/10.1080/09720073.2015.11891883

Atay, D., \& Kurt, G. (2006). Prospective teachers and L2 writing anxiety. Asian EFL Journal Quarterly, 8(4), 100-118. http://asian-efljournal.com/December_2006_EBook.pdf\#page $=100$

Brannan, B. (2003). A writer's workshop: crafting paragraphs, building essays. Glencoe/McGraw-Hill School Publishing Company.

Brown, H. D., \& Lee, H. (2001). Teaching by principles: An interactive approach to language pedagogy. Prentice Hall Regents Englewood Cliffs, NJ.

Creswell, J. W. (2013). Educational research: Planning, conducting, and evaluating quantitative and qualitative research. Pearson.

Eliwarti, E., \& Maarof, N. (2006). The effects of types of writing approaches on EFL students' writing performance. Proceedings of ISELT FBS Universitas Negeri Padang, $2,112-119$.

Fulwiler, T. (2002). College writing a personal approach to academic writing. Boyton/Cook Publisher, inc.

Gonzalez, E. F. (2010). Improving EFL writing through the process approach. University of Brimingham.

Gustilo, L., \& Magno, C. (2015). Explaining L2 writing performance through a chain of predictors: A SEM approach. 3L: The Southeast Asian Journal of English Language Studies, 21(2), 115-130. https://doi.org/10.17576/3L-2015-2102-09

Habtamu, S. A. (2018). The practice of process approach in writing classes: Grade eleven learners of Jimma preparatory and Jimma University community preparatory school in focus. International Journal of English and Literature, 9(5), 39-49. https://doi.org/10.5897/IJEL2018.1158

Harmer, J. (1991). The practice of English language teaching. Longman.

Hasan, M. K., \& Akhand, M. M. (1970). Approaches to writing in EFL/ESL context: Balancing product and process in writing class at tertiary level. Journal of NELTA, 15(1-2), 77-88. https://doi.org/10.3126/nelta.v15i1-2.4612

Hogue, A. (2008). First steps in academic writing (2nd ed.). Pearson. 
Johnson, A. P. (2008). Teaching reading and writing. Rowman and Littlefield Education.

Kim, Y., \& Kim, J. (2005). Teaching Korean University writing class: Balancing the process and the genre approach. Asian EFL Journal, 7(2), 93. http://asian-efljournal.com/June_05_yk\&jk.pdf

McIntyre, E., Hulan, N., \& Layne, V. (2011). Reading instruction for diverse classrooms. Guilford Publication.

Merilia, S., Fajaruddin, S., \& Arbain, A. (2019). An assessment of an English textbook of vocational school. Arisen: Assessment and Research on Education, 1(2). https://doi.org/10.33292/arisen.v1i2.46

Nabhan, S. (2016). The process approach to improve students' writing ability in English education department University of PGRI Adi Buana Surabaya. Jembatan Merah: Jurnal Pengajaran Bahasa Dan Sastra, 13, 0-15. https://karyailmiah.unipasby.ac.id/wpcontent/uploads/2017/03/THE-PROCESS-APPROACH.pdf

Nunan, D. (1991). Language Teaching Methodology. Prentice Hall International English Language Teaching.

Nunan, D. (2003). Practical English langage teaching. Prentice Hall International English Language Teaching.

Oshima, A., \& Hogue, A. (2007). Introduction to academic writing (3rd ed.). Pearson Education.

Ratminingsih, N. M. (2015). The use of personal photographs in writing in a project-based language learning: A case study. The New English Teacher, 9(1), 102-118. http://www.assumptionjournal.au.edu/index.php/newEnglishTeacher/article/view/550

Ratminingsih, N. M., Marhaeni, A. A. I. N., \& Vigayanti, L. P. D. (2018). Self-assessment: The effect on students' independence and writing competence. International Journal of Instruction, 11(3), 277-290. https://doi.org/10.12973/iji.2018.11320a

Samsudin, Z. (2016). Comparing the process approach with the product approach in teaching academic writing to first-year undergraduates. AJELP: The Asian Journal Of English Language And Pedagogy, 4, 84-104. https://ejournal.upsi.edu.my/index.php/AJELP/article/view/1263

Sharifi, A., \& Hassaskhah, J. (2011). The role of portfolio assessment and reflection on process writing. Asian EFL Journal, 13(1), 193-223. https://www.asian-efljournal.com/PDF/March-2011-as.pdf

Sheir, A. A., Zahran, F. A. A., \& Koura, A. A. (2015). The effectiveness of process writing approach in developing EFL writing performance of ESP college students. Educations Sciences Journal.

Singh, Y. K. (2006). Fundamental research methodology and statistics. New Age International.

Sun, C., \& Feng, G. (2009). Process approach to teaching writing applied in different teaching models. English Language Teaching, 2(1), 150-155. https://doi.org/10.5539/elt.v2n1p150

Suwanarak, K. (2018). Self-evaluation of Thai adult learners in English writing practice. $3 L$ The Southeast Asian Journal of English Language Studies, 24(2), 95-111. https://doi.org/10.17576/3L-2018-2402-08

Suwastini, N. K. ., \& Yukti, W. G. S. (2017). Errors analysis in short biography text written by the 11th grade students of a vocational high school in Singaraja. International Journal of Language and Literature, 1(1), 1. https://doi.org/10.23887/ijll.v1i1.9612 
Vanderpyl, G. D. (2012). The Process approach as writing instruction in EFL (English as a Foreign Language) classrooms [SIT Graduate Institute, Brattleboro]. In MA TESOL Collection. https://digitalcollections.sit.edu/ipp_collection/545/

Yusof, N. M. (2009). E-method in literacy production: Intergrating e-learning in creative writing. 3L: Language, Linguistics, Literature, 14, 127-148.

http://ejournals.ukm.my/31/article/view/1023 